\title{
Feasibility Study of Natural Coagulants for Drinking Water
}

\author{
Yash Jadhav $^{1}$, Shivanshu Dubey ${ }^{2}$, Harshal Gawad ${ }^{3}$, Bipin Pandey ${ }^{4}$, Dr. B. J. Godboley ${ }^{5}$ \\ ${ }^{1234}$ UG Students, Department of Civil Engineering, St John College of Engineering \& Management, Palghar \\ ${ }^{5}$ Head of Department, Department of Civil Engineering, St John College of Engineering \& Management, Palghar
}

Received on: 25 April, 2021, Revised on: 21 May,2021, Published on: 23 May, 2021

\begin{abstract}
Now a day's more interest has been concentrated on the identification of natural and alternative coagulant materials. In this study, a natural coagulant like Soya-bean seed, Mustard seed, Pumpkin seeds and Watermelon seeds were suggested as a substitute for alum. It is readily available and commonly recognizable in most urban and rural communities. The powdered material is obtained from the seeds were used to test coagulant rate and dose. This study mainly focused on the removal of turbidity, total dissolved solids (TDS), Hardness and pH of sample. Turbidity and other chemical characteristics of surface water sample were measured before and after the Jar test by using portable instruments. The experiments were carried out with coagulant dosage of 0.2, 0.4, 0.6, 0.8, 1.0, 1.2, 1.4, 1.6 $\mathrm{g} / \mathrm{L}$ in raw water sample. The results proved that the use of Soybean, Mustard seeds, Watermelon and Pumpkin seed as new composite coagulant in water treatment is a feasible option in enhancing the reduction performance of turbidity.
\end{abstract}

Keywords- Natural coagulant, soybean seed, Mustard seed, Pumpkin seed, Watermelon seed, Turbidity, TDS, Hardness, $\mathrm{pH}$, etc.

\section{I -INTRODUCTION}

W ater is very important elements that are involved in human life for good health. Today's rapidly growing populations outstrip available water resources, which is especially problematic in developing countries that may be on the verge of water scarcity. In the context of limited water resources and water scarcity, water treatment and recycling procedures constitute one of the alternatives to obtain potable water in future. It is therefore necessary to develop suitable, rapid, and inexpensive water and wastewater treatment methods to remove turbidity, coloration, and heavy metals among other contaminants. Portable water is treated from the raw water sources with the help of coagulationflocculation process to eliminate turbidity in the raw water sources. There are various remediation techniques for the development of water quality. Traditionally, synthetic inorganic chemicals such as alum and ferric chloride are majorly utilized as primary coagulant. But these coagulants are unfavorable to the environment and human. However, the use of such conventional synthetic chemical coagulants raises environmental, safety, and sustainability concerns, surrounding aspects such as high procurement costs, possible human health risk concerns, their effects on the final $\mathrm{pH}$ of the treated water. These issues have led to the pursuit of alternative coagulants in wastewater treatment, with plant-based coagulants emerging as potential Replacements.

\section{II- OBJECTIVES}

- To assess the possibility of using natural coagulants as an alternative to the current 


\section{International Journal of Innovations in Engineering and Science, www.ijies.net}

commercial synthetic coagulant such as aluminum sulphate and to optimize the coagulation process.

- To prepare the material for removal of turbidity.

- To test the efficiency of Mustard seed powder, Soybean powder, Watermelon seed powder and Pumpkin seed powder.

- To compared the most effective natural coagulant.

\section{III- MATERIALS AND METHODS}

\subsection{Soybean}

Soybean, (Glycine max), also called soja bean or soya bean, annual legume of the pea family (Fabaceae) and its edible seed. Soy beans contain significant amounts of phytic acid, dietary minerals and B vitamins. As soybean seeds lose moisture they change from large, kidney bean shaped to smaller and nearly round. When dry, the seed contains about $40 \%$ protein, $21 \%$ oil, $34 \%$ carbohydrates and $5 \%$ ash.

\subsection{Watermelon Seeds}

Watermelon seeds are one of the most nutrient-dense varieties of seeds. They are a rich source of proteins, vitamins, omega 3 and omega 6 fatty acids, magnesium, zinc, copper, potassium and more. The seeds are pretty low in their calorie count, and are rich in many micronutrients like copper, potassium, magnesium, iron, folate and zinc, all of which are important for the body. Watermelon seed contains moisture content ranging from $3.50 \%$ to $10.90 \%$, crude fat $(0.40 \%$ to $13.10 \%)$, crude protein $(3.20 \%$ to $19.20 \%)$ and carbohydrate (46.10\% to $75.50 \%)$.

\subsection{Mustard Seeds}

Mustard seeds are the small round seeds of various mustard plants. The seeds are usually about 1 to 2 millimetres ( 0.039 to 0.079 in) in diameter and may be colored from yellowish white to black. They are an important spice in many regional foods and may come from one of three different plants: black mustard (Brassica nigra), brown Indian mustard (B. juncea), or white/yellow mustard (B. hirta/Sinapis alba). Mustard seeds are used as a spice in Pakistan, India, Sri Lanka, Nepal, and Bangladesh. The seeds are usually fried until they pop. Mustard seeds contain protein (24.9\%), crude fiber $(14.7 \%)$, carbohydrates (34.94\%), sugar (6.89\%). Mustard seeds contain protein $(26.08 \%)$, crude fiber $(12.2 \%)$, carbohydrates $(28.09 \%)$, fat $(33.63 \%)$ on dry weight basis.

\subsection{Pumpkin Seeds}

The seeds are typically flat and asymmetrically oval, have a white outer husk, and are light green in color after the husk is removed. Some cultivars are huskless, and are grown only for their edible seed. The seeds are nutrient and calorie rich, with especially high content of fat (particularly linoleic acid and oleic acid), protein, dietary fiber, and numerous micronutrients. The seeds are typically flat and asymmetrically oval, have a white outer husk, and are light green in color after the husk is removed. Some cultivars are huskless, and are grown only for their edible seed. The seeds are nutrient and calorie rich, with especially high content of fat (particularly linoleic acid and oleic acid), protein, dietary fiber, and numerous micronutrients.

\subsection{Preparation of Bio-coagulants}

The mature Soyabean, Mustard seeds, Watermelon seeds and Pumpkin seeds were purchased from market. The Seeds were then dried in sunlight for 3-4 days and ground to a fine powder using a domestic grinder. Fine powder were then sieved through a $300 \mu$. After drying, powder was left to cool and packed into clean polythene bags and sealed. The bags were kept in freshness and dryness for further use.

\subsection{Collection of Water}

Used water (wastewater) is collect from college campus (SJCEM). Add $5 \mathrm{~g}$ of soil passing through IS Sieve $300 \mu$ in 1 litre of water to make water turbid.

\subsection{Experimental Jar Test:}

Fill the jar testing apparatus containers with 1 litre of sample water. Add the coagulant $(0.2 \mathrm{~g}, 0.4 \mathrm{~g}$, $0.6 \mathrm{~g}, \ldots, 2 \mathrm{~g}$ ) to each container and stir at approximately $100 \mathrm{rpm}$ for 1 minute. The rapid mix stage helps to disperse the coagulant throughout each container. Reduce the stirring speed to $55 \mathrm{rpm}$ and continue mixing for 15 minutes. This slower mixing speed helps promote floc formation by enhancing particle collisions which lead to larger flocs. Turn off the mixers and allow the containers to settle for 30 minutes. Then measure the final turbidity in each container. The optimum dosage can be calculated by calculating the best turbidity removal percentage for the coagulant. 


\section{International Journal of Innovations in Engineering and Science, www.ijies.net}
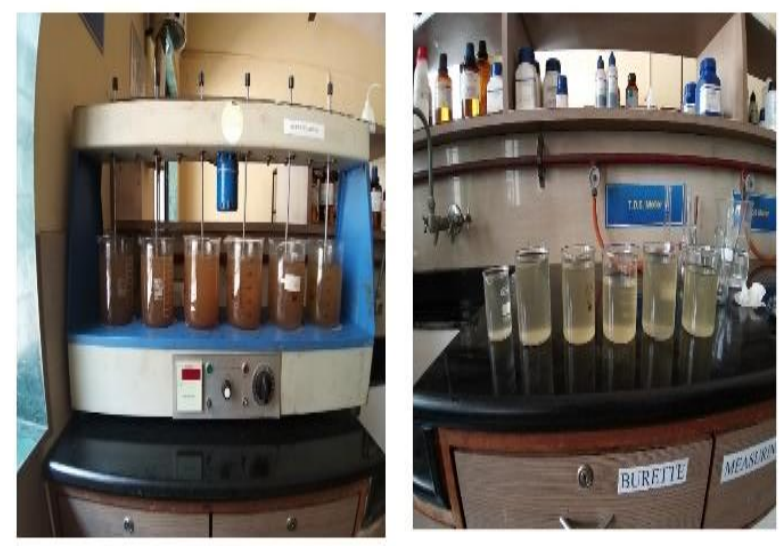

Fig.1- Jar test

After finding optimum dosage proceed for other test i.e. pH, Total Dissolve Solids (TDS) and Hardness. pH and TDS can be measures with the help of Digital $\mathrm{pH}$ meter and Digital TDS meter respectively. Hardness of water can be measured by EDTA method.

\section{IV-RESULT}

Initial Reading of sample raw water was Turbidity, $\mathrm{pH}$, TDS and Hardness of raw water measured as17.93 NTU, 8.6, 118ppm and 110ppm respectively.

\subsection{Soyabean seeds}

Table 1- Turbidity Removal using Soybean

\begin{tabular}{|c|c|c|c|}
\hline Dosage & Turbidity & $\%$ & $\begin{array}{c}\text { Turbidity } \\
\text { Removal }\end{array}$ \\
\hline $0.2 \mathrm{~g}$ & 14.23 & 20.64 & 79.36 \\
\hline $0.4 \mathrm{~g}$ & 14.97 & 16.51 & 83.49 \\
\hline $0.6 \mathrm{~g}$ & 15.57 & 13.16 & 86.84 \\
\hline $0.8 \mathrm{~g}$ & 15.17 & 15.39 & 84.61 \\
\hline $1 \mathrm{~g}$ & 15.77 & 12.05 & 87.95 \\
\hline $1.2 \mathrm{~g}$ & 16.20 & 9.65 & 90.35 \\
\hline $1.4 \mathrm{~g}$ & 17.3 & 3.51 & 96.49 \\
\hline $1.6 \mathrm{~g}$ & 17.8 & 0.73 & 99.27 \\
\hline $1.8 \mathrm{~g}$ & 17.87 & 0.33 & 99.67 \\
\hline $2 \mathrm{~g}$ & 17.4 & 2.96 & 97.04 \\
\hline
\end{tabular}

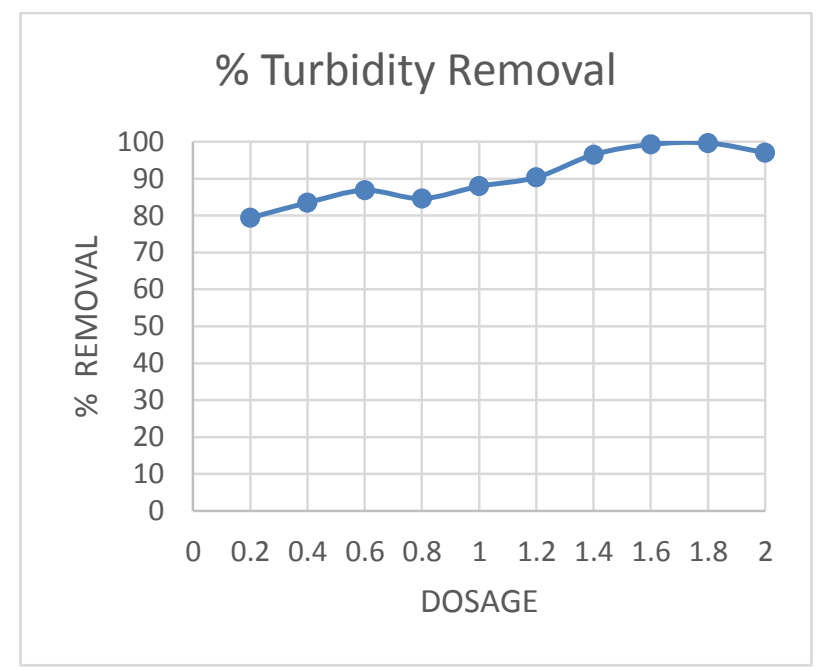

Fig.2-Graph of Turbidity removal using Soybean

Optimum dosage found at $1.8 \mathrm{~g}$ and turbidity removal is $99.67 \%, \mathrm{pH}$, TDS, Hardness is obtained as 7.8, 107ppm, 90ppm respectively.

\subsection{Mustard Seeds}

Table.2 -Turbidity Removal using Mustard seeds

\begin{tabular}{|c|c|c|c|}
\hline Dosage & Turbidity & $\%$ & $\begin{array}{c}\text { Turbidity } \\
\text { Removal }\end{array}$ \\
\hline $0.2 \mathrm{~g}$ & 11.6 & 35.30 & 64.70 \\
\hline $0.4 \mathrm{~g}$ & 9.9 & 44.79 & 55.21 \\
\hline $0.6 \mathrm{~g}$ & 13.06 & 27.16 & 72.84 \\
\hline $0.8 \mathrm{~g}$ & 15.06 & 16.01 & 84 \\
\hline $1 \mathrm{~g}$ & 13.56 & 24.37 & 75.63 \\
\hline $1.2 \mathrm{~g}$ & 16.03 & 10.60 & 89.40 \\
\hline $1.4 \mathrm{~g}$ & 15.9 & 11.32 & 88.68 \\
\hline $1.6 \mathrm{~g}$ & 15.5 & 13.55 & 86.45 \\
\hline
\end{tabular}

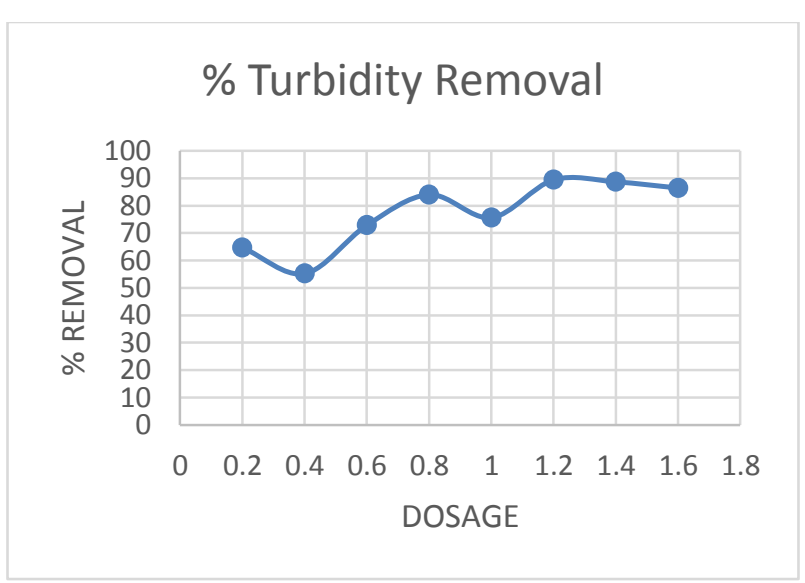

Fig.3- Graph of Turbidity removal using Mustard seeds 


\section{International Journal of Innovations in Engineering and Science, www.ijies.net}

Optimum dosage found at $1.2 \mathrm{~g}$ and turbidity removal is $89.40 \%, \mathrm{pH}$, TDS, Hardness is obtained as 7.6, 98ppm, $107.5 \mathrm{ppm}$ respectively.

\subsection{Watermelon Seeds}

Table 3- Turbidity Removal using Watermelon seeds

\begin{tabular}{|c|c|c|c|}
\hline Dosage & Turbidity & $\%$ & $\begin{array}{c}\text { Turbidity } \\
\text { Removal }\end{array}$ \\
\hline $0.2 \mathrm{~g}$ & 12.83 & 28.44 & 71.56 \\
\hline $0.4 \mathrm{~g}$ & 15.33 & 14.50 & 85.5 \\
\hline $0.6 \mathrm{~g}$ & 15.67 & 12.60 & 87.40 \\
\hline $0.8 \mathrm{~g}$ & 15.87 & 11.49 & 88.51 \\
\hline $1 \mathrm{~g}$ & 15.37 & 14.28 & 85.72 \\
\hline $1.2 \mathrm{~g}$ & 15.43 & 13.94 & 86.06 \\
\hline
\end{tabular}

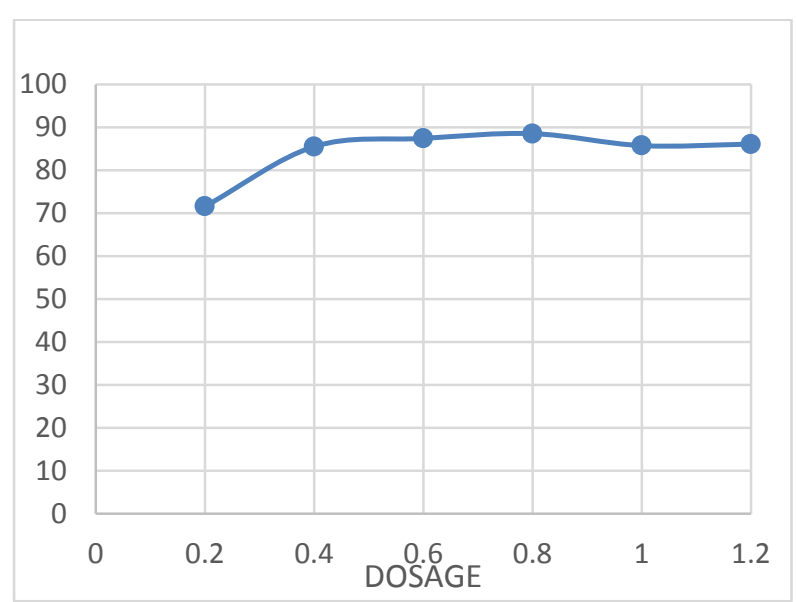

Fig.4- Graph of Turbidity removal using Watermelon seeds

Optimum dosage found at $0.8 \mathrm{~g}$ and turbidity removal is $88.51 \%, \mathrm{pH}$, TDS, Hardness is obtained as 8.2, $115 \mathrm{ppm}$, $100 \mathrm{ppm}$ respectively.

4.4 Pumpkin Seeds Optimum dosage found at $0.8 \mathrm{~g}$ and turbidity removal is $88.51 \%, \mathrm{pH}$, TDS, Hardness is obtained as $8.2,115 \mathrm{ppm}, 100 \mathrm{ppm}$ respectively.

Table 4- Turbidity Removal using Pumpkin seeds

\begin{tabular}{|c|c|c|c|}
\hline Dosage & 11.69 & 34.80 & 65.20 \\
\hline $0.4 \mathrm{~g}$ & 14.57 & 18.74 & 81.26 \\
\hline $0.6 \mathrm{~g}$ & 14.23 & 20.64 & 79.36 \\
\hline $0.8 \mathrm{~g}$ & 14.87 & 17.07 & 82.93 \\
\hline $1 \mathrm{~g}$ & 14.93 & 16.73 & 83.27 \\
\hline $1.2 \mathrm{~g}$ & 15.90 & 11.32 & 88.68 \\
\hline $1.4 \mathrm{~g}$ & 16.23 & 9.48 & 90.52 \\
\hline $1.6 \mathrm{~g}$ & 16.57 & 7.6 & 92.40 \\
\hline $1.8 \mathrm{~g}$ & 16.5 & 7.98 & 92.02 \\
\hline $2 \mathrm{~g}$ & 16.0 & 10.21 & 89.79 \\
\hline
\end{tabular}

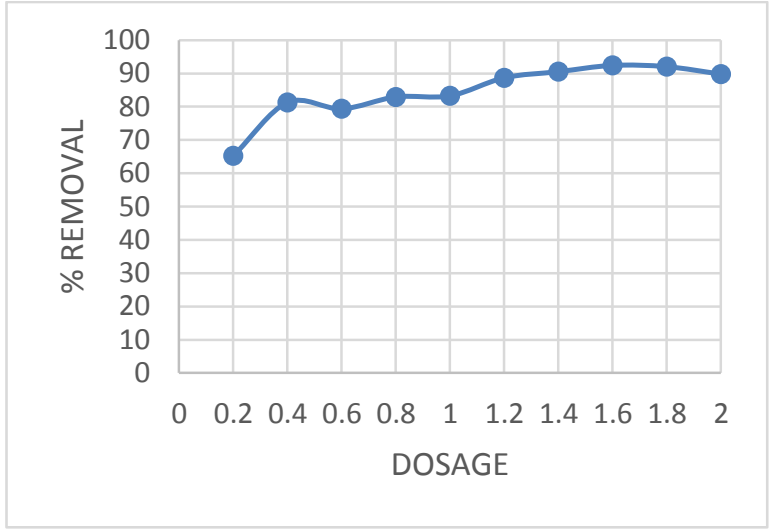

Fig.5- Graph of Turbidity removal using Pumpkin seeds

Optimum dosage found at $1.6 \mathrm{~g}$ and turbidity removal is $92.40 \%, \mathrm{pH}$, TDS, Hardness is obtained as 7.6, 110ppm, 90ppm respectively.

\section{V- CONCLUSION}

This Study mainly focuses on the removal of turbidity. The experiment was done to determine and compare the efficiency of natural coagulants such as soyabean powder, mustard seed powder, watermelon seed powder and pumpkin seed powder as an effective coagulant in treating the synthetic waste water. Turbidity reduction of soyabean powder, mustard seed powder, watermelon seed powder and pumpkin seed powder is $99.67 \%, 89.40 \%, 88.51 \%$ and $92.40 \%$ respectively. $\mathrm{PH}$ reading of soyabean powder, mustard seed powder, watermelon seed powder and pumpkin seed powder after jar test 7.8,7.6,8.2 and 7.6. TDS (Total Dissolved Solids) of soyabean powder, mustard seed powder, watermelon seed powder and pumpkin seed powder after jar test 107PPM, 98PPM, 115PPM, and 110PPM. Hardness of soyabean powder, mustard seed powder, watermelon seed powder and pumpkin seed powder after jar test 90PPM, 107.5PPM, 100PPM and 90PPM. Natural coagulants does not guarantee that the raw water ends up completely free of pathogenic germs. It is cleaned and drinkable but not completely purified. The $\mathrm{PH}$ reading was slightly similar before and after treatment. From the result obtained it is clear that the natural bio--coagulants can be used for treating waste water. It is eco-friendly and provides cheaper method of water treatment. Hence it can be concluded that natural materials like soyabean, mustard seed, watermelon seed and pumpkin seed can be used for treatment of water. 


\section{International Journal of Innovations in Engineering and Science, www.ijies.net}

\section{REFERENCES}

[1] Water Supply and Sanitary Engineering by S. C. Rangwala.

[2] Rubini $S$, Balamurugan $P$, Shunmugapriya $K$, 'Exploring the use of Neem Leaf Powder as an Alternative Coagulant in Treatment of Wastewater', International Journal of Recent Technology and Engineering (IJRTE) ISSN: 2277-3878, Volume-8 Issue-2, July 2019.

[3] Syeda Azeem Unnisa, Shaik Zainab Bi, 'Carica papaya seeds effectiveness as coagulant and solar disinfection in removal of turbidity and coliforms', Applied Water Science, 2 August 2018

[4] Arya Chandran J, Duithy George, 'Use of Papaya Seed as a Natural Coagulant for Water Purification', Environmental Engineering \& Management, Department of Civil Engineering UKF College of Engineering and Technology, Parippally Kollam, International Journal of Scientific Engineering and Research (IJSER) ISSN (Online): 2347-3878, March 2018

[5] M. Mathuram, R. Meera , G. Vijayaraghavan, 'Application of Locally Sourced Plants as Natural Coagulants For Dye Removal from Wastewater Department of Biotechnology', Rajalakshmi Engineering College, Chennai, India, Journal of Materials and Environmental Sciences, Volume 9, Issue 7, Jan 2018

[6] Saravanan J, Priyadharshini D, Soundammal A, Sudha $G$, Suriyakala $K$, 'Wastewater Treatment using Natural Coagulants', Renganayagi Varatharaj College of Engineering, Sivakasi, India, International Journal of Civil Engineering (SSRGIJCE) - volume 4 Issue 3 - March 2017
[7] Parthiban L, Porchelvan P, Ramasamy T, 'Clarification and Disinfection of Water Using Natural Herbs (Neem) Azadirachta Indica', Shyamala Gowri School of Civil and Chemical Engineering, VIT University, Journal of Chemical and Pharmaceutical Sciences, March 2017

[8] Rubini $S$, Balamurugan $P$, Shunmugapriya. $K$, 'Exploring the use of Cactus and Neem Leaf Powder as an alternative coagulant in treatment of wastewater', International Journal of Recent Technology and Engineering (IJRTE) ISSN: 22773878, Volume-8 Issue-2, July 2019

[9] Zuraisah Dollah, Ummu Habibah Abd Rahman, Nurakmal Hamzah, Daliah Hasan1, Siti Rahimah Rosseli, 'Potential of Orange Peels as Natural Coagulant in Water Treatment', Faculty of Civil Engineering, Universiti Teknologi MARA, Pulau Pinang, MALAYSIA, researchgate.net, Dec 2014

[10] Habsah Alwi, Juferi Idris, Mohibah Musa and Ku Halim Ku Hamid, 'A Preliminary Study of Banana Stem Juice as a Plant-Based Coagulant for Treatment of Spent Coolant Wastewater', Faculty of Chemical Engineering, University Teknologi MARA, Malaysia, 40450 Shah Alam, Selangor, Malaysia, Hindawi Publishing Corporation Journal of Chemistry Volume 2013, Article ID 165057, Jan 2013

[11] Dishna Schwarz, 'Water Clarification using Moringa oleifera', Gate Information Service, Technical Information Wle June 2000

[12] Fladerer F, Krist H., Rohowski G. ,Schneider W. 1995, 'A comparative study of Methods of Desinfecting Drinking water in Developing Countries', GTZ, Eschborn. 